\title{
An efficient cis-reduction of alkyne to alkene in the presence of a vinyl iodide: stereoselective synthesis of the C22-C31 fragment of leiodolide $A$
}

\author{
Xing Zhang ${ }^{a, b}$, Jun Liu ${ }^{a, *}$, Xue Sun ${ }^{a, b}$, Yuguo Du ${ }^{a, b, *}$ \\ ${ }^{a}$ State Key Laboratory of Environmental Chemistry and Eco-toxicology, Research Center for Eco-Environmental Sciences, Chinese Academy of Sciences, Beijing 100085, China \\ ${ }^{\mathrm{b}}$ School of Chemistry and Chemical Engineering, University of Chinese Academy of Sciences, Beijing 100049, China
}

\section{A R T I C L E I N F O}

\section{Article history:}

Received 30 August 2012

Received in revised form 27 November 2012

Accepted 4 December 2012

Available online 10 December 2012

\section{Keywords:}

Vinyl iodide

Alkyne

Cis-reduction

Leiodolides

Stereoselective synthesis

\begin{abstract}
A B S T R A C T
Rapid and efficient reduction of alkyne bond in the presence of a vinyl iodide is established using freshly prepared Brown's P2-Ni as the catalyst, affording the semihydrogenated alkene products in good to excellent yields (73-91\%). Based on this new method, a stereoselective synthesis of the key C22-C31 fragment of marine macrolide leiodolide $\mathrm{A}$ has been developed.
\end{abstract}

(c) 2012 Elsevier Ltd. All rights reserved.

\section{Introduction}

Vinyl iodides, with well-defined geometry structures, have been widely used as important building blocks in organic natural product synthesis, owing to the valuable application of the transitionmetal catalyzed cross-coupling reactions, such as Heck, Sonogashira, and Suzuki-Miyaura reactions, et al. ${ }^{1,2}$ Efficient methods for the preparation of stereodefined vinyl iodide structures, employing as synthons in $\mathrm{C}-\mathrm{C}$ bond formation, have been investigated through introducing the iodide at the very end reaction sequence. ${ }^{3}$ Very few studies have been made regarding the stability and compatibility of vinyl iodide in functional group modification and transformation. ${ }^{4}$ It is generally believed that vinyl iodide could not survive under most of the common reduction conditions, leading to the corresponding olefin or saturated carbon-carbon bond, instead. To our best knowledge, the only example of cis-reduction of propargyl alcohol bearing a vinyl iodide was reported by Parker in his synthesis of discodermolide. ${ }^{4 a}$ Herein we report the stereoselective synthesis of the C22-C31 fragment of leiodolide A employing a diastereoselective Seebach alkylation and a Brown's P2-Ni catalyzed alkyne semihydrogenation in the presence of a vinyl iodide.

\footnotetext{
* Corresponding authors. E-mail addresses: junliu@rcees.ac.cn, jeromeorg@yahoo.com.cn (J. Liu), duyuguo@rcees.ac.cn (Y. Du).
}

Leiodolide A (Fig. 1) is a marine natural product originally isolated from the deep-water marine sponge Leiodermatium by Fenical and co-workers in 2006 . $^{5}$ Preliminary biological testing indicated that leiodolide A exhibited significant cytotoxic activity in the $\mathrm{NCI}$ 60 tumor cell line assay, with enhanced activity against HL-60 leukemia and OVCAR-3 ovarian cancer cells. The promising biological activities as well as densely functionalized structures have prompted some efforts toward leiodolide synthesis. ${ }^{6}$

To provide sufficient material for further biological studies, as well as to assign the absolute configuration at $\mathrm{C} 13$, we initiated a study toward the total synthesis of leiodolide $\mathrm{A}$ and its derivatives. Due to the structural complexity of the leiodolide A, our

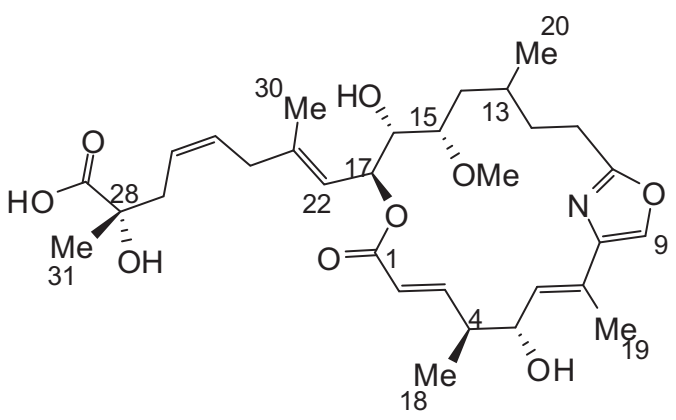

Fig. 1. Proposed structure of leiodolide A. 
synthetic approach involves the synthesis of three distinct fragments $(\mathrm{C} 1-\mathrm{C} 10, \mathrm{C} 11-\mathrm{C} 17$, and $\mathrm{C} 22-\mathrm{C} 31)$ with strategic bond disconnections (Fig. 2). In this report, we describe a convenient strategy for the stereoselective synthesis of fragment C22-C31 (3), the $\alpha$-hydroxy- $\alpha$-methyl carboxylic acid side-chain, based on our new methodology. Thus, precursor 3 could be achieved via a diastereoselective alkylation of the Seebach's dioxolanone ${ }^{7} \mathbf{4}$ with a propargylic bromide $\mathbf{5}$ derived from propargyl alcohol. The key transformation in this synthetic strategy was a semihydrogenation of the C25-C26 internal acetylene. quaternary carbon was assigned as $(S)$-configuration based on literature precedent. $^{7 a}$

With the efficient access to vinyl iodide $\mathbf{8}$, we next examined the semihydrogenation of triple bond under Lindlar reduction condition. ${ }^{11}$ However, the envisaged partial hydrogenation of the alkyne $\mathbf{8}$ in the presence of vinyl iodide, turned out to be more difficult than we expected. Exposure of $\mathbf{8}$ to hydrogen gas in the presence of Lindlar catalyst with or without quinoline only resulted in the recovery of most starting material and some decomposition of the substrate due to hydrogenolysis of the vinyl iodide.
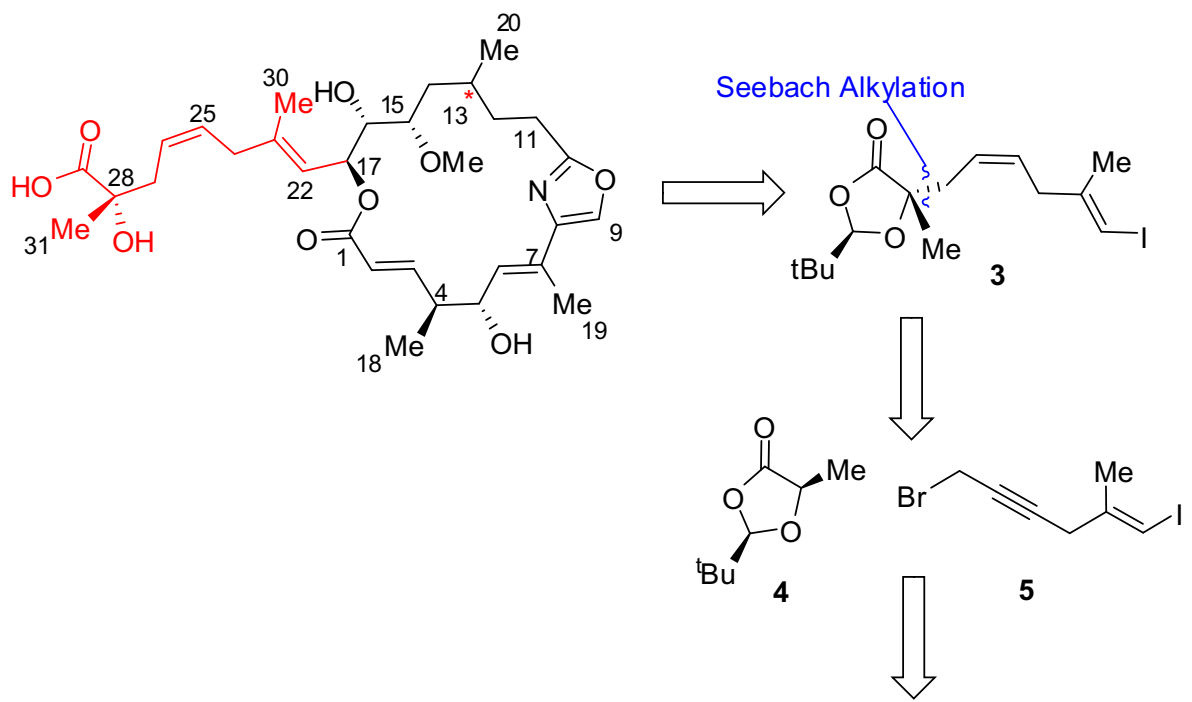

R-Lactic acid

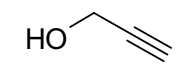

Fig. 2. Retrosynthetic analysis of leiodolide A (1).

\section{Results and discussion}

The synthesis of the fragment $\mathrm{C} 22-\mathrm{C} 31$ of leiodolide $\mathrm{A}$ is outlined in Scheme 1 . The diyne $\mathbf{6}^{8}$ was prepared in a moderate yield by means of copper-mediated cross-coupling reaction between the commercially available propargyl alcohol and propargyl bromide. ${ }^{9}$ Selective carboalumination of the terminal alkyne followed by quenching with iodine afforded vinyl iodide $\mathbf{7}$ as a single isomer in $65 \%$ yield. ${ }^{10}$ The hydroxyl group of 7 was converted into the bromide 5 with $\mathrm{PPh}_{3} / \mathrm{CBr}_{4}$ in dichloromethane. Subsequent treatment of Seebach's $(R)$-lactic acid-derived dioxolanone $\mathbf{4}$ with LDA at $-90{ }^{\circ} \mathrm{C}$ followed by the addition of propargyl bromide $\mathbf{5}$ furnished compound $\mathbf{8}$ in $85 \%$ yield and greater than 20:1 dr according to the crude NMR. ${ }^{7}$ The absolute stereochemistry of the newly formed
To circumvent this problem, we chose the more easily available alcohol $\mathbf{7}$ as a suitable model compound, and its semihydrogenation was investigated under a variety of different reaction conditions (Table 1 ).

Treatment of $\mathbf{7}$ with $1 \mathrm{~atm}$ of hydrogen gas in the presence of Lindlar catalyst with a catalytic amount of quinoline in ethyl acetate or methanol resulted in the recovery of starting material (entries 1 and 2). Attempts to semi-reduce the triple bond in the absence of quinoline also failed and only returned alcohol 7 (entries 3 and 4). Literature searching revealed that the reduction of propargyl alcohol to cis-allylic alcohol, in the presence of a vinyl iodide, could be carried out at $\mathrm{H}_{2}$ atmosphere using $\mathrm{Pd} / \mathrm{CaCO}_{3}$ in hexane. ${ }^{4 a}$ To our depressing, hydrogenation under this condition, or at $\mathrm{H}_{2}$ pressures as high as $4 \mathrm{~atm}$, also resulted in the recovered starting material<smiles>CC#CCOCC#CCC#CCCCC</smiles>

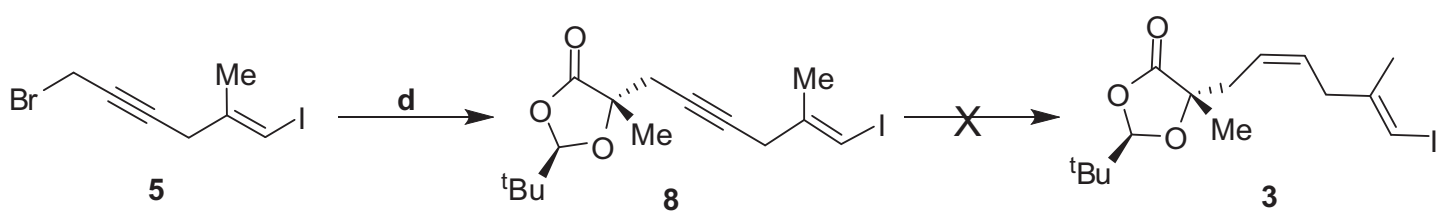

Scheme 1. Attempted synthesis of compound 3: (a) propargyl bromide, $\mathrm{Et}_{3} \mathrm{~N}, \mathrm{CuI}, \mathrm{DMF}, \mathrm{Et}_{2} \mathrm{O}, 54 \%$; (b) $\mathrm{ZrCp}_{2} \mathrm{Cl}_{2}, \mathrm{AlMe}_{3}, \mathrm{DCM}$, room temperature, then $\mathrm{I}_{2}, \mathrm{Et}_{2} \mathrm{O}, 0{ }^{\circ} \mathrm{C}, 65 \%$; (c) $\mathrm{CBr}_{4}$, $\mathrm{PPh}_{3}, \mathrm{DCM}, 0{ }^{\circ} \mathrm{C}, 89 \%$; (d) $4, \mathrm{LDA}, \mathrm{THF},-90^{\circ} \mathrm{C}, 10 \mathrm{~min}$, then $5,-78{ }^{\circ} \mathrm{C}, 2 \mathrm{~h}, 85 \%$. 
Table 1

Screening the semihydrogenation conditions of alkyne in the presence of vinyl iodide

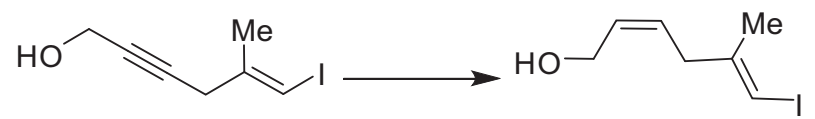

7

9

\begin{tabular}{|c|c|c|c|}
\hline \multicolumn{2}{|c|}{ Entry Conditions } & \multicolumn{2}{|c|}{ Product Yield (\%) } \\
\hline 1 & Lindlar catalyst, ${ }^{\mathrm{b}}$ quinoline, ethyl acetate, $\mathrm{H}_{2}$ (1 atm), $5 \mathrm{~h}$ & $1-$ & $\mathrm{ND}^{\mathrm{C}}$ \\
\hline 2 & Lindlar catalyst, quinoline, methanol, $\mathrm{H}_{2}(1 \mathrm{~atm}), 5 \mathrm{~h}$ & - & ND \\
\hline 3 & Lindlar catalyst, ethyl acetate, $\mathrm{H}_{2}(1 \mathrm{~atm}), 5 \mathrm{~h}$ & - & ND \\
\hline 4 & Lindlar catalyst, methanol, $\mathrm{H}_{2}$ (1 atm), $5 \mathrm{~h}$ & - & ND \\
\hline 5 & $\mathrm{Pd} / \mathrm{CaCO}_{3}$, hexane, $\mathrm{H}_{2}(1 \mathrm{~atm}), 10 \mathrm{~h}$ & - & ND \\
\hline 6 & $\mathrm{Pd} / \mathrm{CaCO}_{3}$, hexane, $\mathrm{H}_{2}(4 \mathrm{~atm}), 10 \mathrm{~h}$ & - & ND \\
\hline 7 & $\mathrm{Zn},{ }^{\mathrm{d}} \mathrm{MeOH} / \mathrm{H}_{2} \mathrm{O}, 30^{\circ} \mathrm{C}, 4 \mathrm{~h}$ & - & ND \\
\hline 8 & Zn, 1,2-dibromoethane, EtOH, reflux, $4 \mathrm{~h}$ & - & ND \\
\hline 9 & $\mathrm{P} 2-\mathrm{Ni},{ }^{\mathrm{e}}$ EtOH, $\mathrm{H}_{2}(1 \mathrm{~atm}), 10 \mathrm{~h}$ & 9 & $42^{\mathrm{a}}$ \\
\hline 10 & $\mathrm{P} 2-\mathrm{Ni}^{\mathrm{f}}{ }^{\mathrm{E}} \mathrm{EtOH}, \mathrm{H}_{2}(1 \mathrm{~atm}), 4 \mathrm{~min}$ & 9 & $77^{\mathrm{a}}$ \\
\hline
\end{tabular}

a Isolated yield.

b Approximately $5 \% \mathrm{Pd} / \mathrm{CaCO}_{3}$, poisoned with lead.

c No desired product.

d The $\mathrm{Zn}$ dust was activated by stirring it in a $0.1 \mathrm{M} \mathrm{HCl}$ solution for ca. $15 \mathrm{~min}$.

e $\mathrm{Ni}(\mathrm{OAc})_{2} \cdot 4 \mathrm{H}_{2} \mathrm{O}$ (0.5 equiv), $\mathrm{NaBH}_{4}(0.5$ equiv), and ethylenediamine ( 0.2 equiv) were used at room temperature.

${ }^{f} \mathrm{Ni}(\mathrm{OAc})_{2} \cdot 4 \mathrm{H}_{2} \mathrm{O}$ (3.0 equiv), $\mathrm{NaBH}_{4}$ (3.0 equiv), and ethylenediamine (1.2 equiv) were used at room temperature.

(entries 5 and 6). We felt that the conventional methods using poisoned heterogeneous Pd-catalysts may not work for this semihydrogenation. So we turned our efforts to other metal catalysts, such as activated zinc in methanol $/ \mathrm{H}_{2} \mathrm{O}^{12 \mathrm{a}}$ or $\mathrm{Zn} / \mathrm{BrCH}_{2} \mathrm{CH}_{2} \mathrm{Br}$ system, ${ }^{12 \mathrm{~b}}$ but failed to generate the desired products (entries 7 and 8 ).

After considerable experimentation, to our delight, the partial reduction was finally achieved and afforded the clean cis-reductive product in moderate yield (42\%) with 0.5 equiv of Brown's P2-Ni catalyst, ${ }^{13}$ which is generated in situ by reduction of nickel acetate with sodium borohydride in anhydrous ethanol. It is worth noting that the loading amount of P2-Ni catalyst is critical to the reaction. If the amount was less than 1.0 equiv, the yield could not be improved significantly even at prolonged reaction time. By adding over 2.5 equiv of catalyst, we observed the good yields (72-77\%) and shorten reaction time (2-10 min) during screening the suitable reaction conditions. The reaction conditions were eventually optimized and set to 3.0 equiv freshly prepared P2-Ni as the catalyst, anhydrous ethanol as the solvent, and the reaction could proceed at room temperature.

To investigate the reaction scope, we further expanded the method to other substrates under the optimized conditions (Table 2). As expected, TBS and Bz groups were compatible to the reaction conditions, and partial hydrogenation of the protected propargyl alcohols $\mathbf{1 0}$ and 12, in the presence of vinyl iodide, was achieved with excellent selectivity and high yields (entries 2 and 3 ). It was found that electron-donating substituent (TBS) at the hydroxyl group favored product formation, whereas an electronwithdrawing group $(\mathrm{Bz})$ hindered product formation and took much longer reaction time. In addition, the terminal alkyne $\mathbf{1 4}$ could be reduced to the terminal alkene $\mathbf{1 5}$ in good yield (entry 4). The disubstituted vinyl iodide $\mathbf{1 6}$ also provided the corresponding alkene $\mathbf{1 7}$ in $81 \%$ yield (entry 5 ). It is interesting to note that, for the 1,4-diyne 18, terminal alkene intermediate 19 could be trapped cleanly under our partial reduction conditions (entry 6), whereas, 1,4-diene 20 was generated with much longer reaction time (entry 7). Entries 6 and 7 also suggest the possibility of selectively obtaining terminal alkene for partial reduction of diyne by using Brown's P2-Ni as the catalyst. To our delight, the reaction proceeded smoothly to afford the designed product even in a large scale (entry $1, \mathbf{7} \rightarrow \mathbf{9}, 1.0 \mathrm{mmol}$ ) and no over-reduction product was observed. ${ }^{14}$ Finally, the partial reduction of the alkyne 8 under optimized conditions, in $3 \mathrm{~min}$, accomplished the synthesis of the target fragment C22-C31 3 in 79\% yield (entry 8). In all cases studied here, the cis-olefins were formed cleanly without any detectable over-reduction products. The current results clearly demonstrate the potential usage of this method to structurally related natural product synthesis.

\section{Conclusion}

A practical method for the cis-reduction of alkyne to alkene has been developed employing Brown's P2-Ni as the catalyst. This new approach allows the presence of vinyl iodide in the reduction substrates. Based on this finding, a successful stereoselective synthesis of the key C22-C31 fragment of the marine macrolide leiodolide A has been achieved in five steps from propargyl alcohol with $21 \%$ overall yield. The completion of natural leiodolide A synthesis is currently underway in our laboratory.

\section{Experimental section}

\subsection{General experimental}

All reactions were performed under a nitrogen atmosphere and solvents were dried according to the established procedures ahead of use. All reagents were purchased from commercial corporations. Flash chromatography (FC) was performed using E Merck silica gel 60 (240-400 mesh). All reactions under standard conditions were monitored by thin-layer chromatography (TLC) on gel $F_{254}$ plates. Optical rotations were recorded on a polarimeter. Infrared spectra were recorded on a Perkin-Elmer 1000 series FTIR with wave numbers expressed in $\mathrm{cm}^{-1}$ using samples prepared as thin films between salt plates. HRMS were measured with mass spectrometer. ${ }^{1} \mathrm{H}$ NMR and ${ }^{13} \mathrm{C}$ NMR were measured on $400 \mathrm{MHz}$ spectrometers (NMR in $\mathrm{CDCl}_{3}$ with TMS as an internal standard). Chemical shifts $(\delta)$ are given in parts per million relative to residual solvent (usually chloroform; $\delta 7.26$ for ${ }^{1} \mathrm{H}$ NMR or 77.23 for proton decoupled ${ }^{13} \mathrm{C}$ NMR), and coupling constants $(J)$ in hertz. Multiplicity is tabulated as s for singlet, $\mathrm{d}$ for doublet, $\mathrm{t}$ for triplet, $\mathrm{q}$ for quadruplet, and $\mathrm{m}$ for multiplet, whereby the prefix app is applied in cases where the true multiplicity is unresolved, and $b r$ when the signal in question is broadened.

4.1.1. Hexa-2,5-diyn-1-ol (6). To a solution of propargyl alcohol $(50 \mathrm{mg}, 0.893 \mathrm{mmol})$ in $\mathrm{Et}_{2} \mathrm{O}(0.6 \mathrm{~mL})$ and $\mathrm{DMF}(0.2 \mathrm{~mL})$ at room temperature were added $\mathrm{CuI}\left(170 \mathrm{mg}, 0.893 \mathrm{mmol}\right.$ ) and $\mathrm{Et}_{3} \mathrm{~N}$ (90 $\mathrm{mg}, 0.893 \mathrm{mmol}$ ). After $5 \mathrm{~min}$, a solution of propargyl bromide (105 $\mathrm{mg}, 0.893 \mathrm{mmol})$ in $\mathrm{Et}_{2} \mathrm{O}(0.4 \mathrm{~mL})$ was added, and the reaction mixture was stirred vigorously for $3.5 \mathrm{~h}$. Then the mixture was treated with satd $\mathrm{NH}_{4} \mathrm{Cl}$ solution $(0.5 \mathrm{~mL})$. The crude reaction mixture was filtered through a Celite pad and the organic layer was removed under reduced pressure and extracted with $\mathrm{Et}_{2} \mathrm{O}$ $(3 \times 20 \mathrm{ml})$. The combined organic layers were washed with aqueous brine, dried over $\mathrm{Na}_{2} \mathrm{SO}_{4}$, and concentrated under vacuum. The crude was purified by FC (silica gel, hexanes/EtOAc 6:1) to give known compound 6 as a light yellow oil (45 mg, 54\%). ${ }^{1} \mathrm{H}$ NMR $\left(400 \mathrm{MHz}, \mathrm{CDCl}_{3}\right) \delta: 4.25(\mathrm{t}, J=2.0,2 \mathrm{H}), 3.21(\mathrm{dd}, J=2.0,4.8,2 \mathrm{H}), 2.08$ $(\mathrm{t}, J=2.8,1 \mathrm{H}), 1.95$ (br s, $1 \mathrm{H}) ;{ }^{13} \mathrm{C} \mathrm{NMR}\left(100 \mathrm{MHz}, \mathrm{CDCl}_{3}\right) \delta 79.2,79.1$, 77.8, 69.1, 51.1, 9.6; IR (film, $\mathrm{cm}^{-1}$ ): 3290, 2291, 2227, 2126.

4.1.2. (E)-6-Iodo-5-methylhex-5-en-2-yn-1-ol (7). To a solution of bis(cyclopentadienyl)zirconium dichloride $(565 \mathrm{mg}, 1.934 \mathrm{mmol})$ in dry DCM $(7 \mathrm{~mL})$ at $0{ }^{\circ} \mathrm{C}$ was added $\mathrm{AlMe}_{3}$ (6.286 mmol, 6.5 equiv) dropwise. After stirring for $45 \mathrm{~min}$ at room temperature, alkyne 6 (91 $\mathrm{mg}, 0.967 \mathrm{mmol})$ in DCM $(1.5 \mathrm{ml})$ was added dropwise. The reaction mixture was stirred at room temperature for $30 \mathrm{~h}$ and then cooled to $0{ }^{\circ} \mathrm{C}$, followed by the addition of iodide $(828 \mathrm{mg}$, 
Table 2

Semihydrogenation of alkynes in the presence of vinyl iodide using P2-Ni catalyst

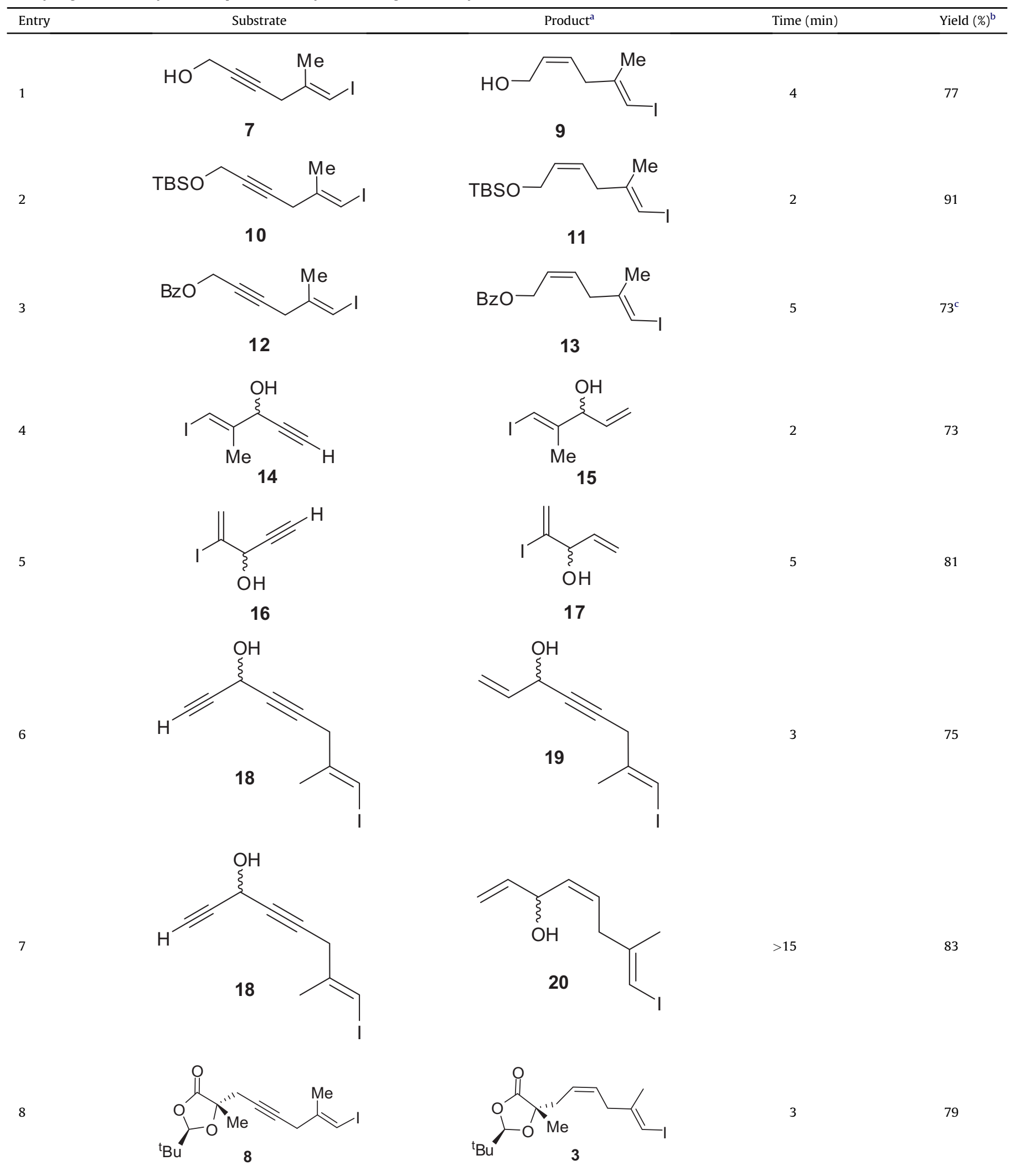

${ }^{a}$ Unless otherwise noted, $\mathrm{Ni}(\mathrm{OAc})_{2} \cdot 4 \mathrm{H}_{2} \mathrm{O}$ (3.0 equiv), $\mathrm{NaBH}_{4}$ (3.0 equiv), and ethylenediamine (1.2 equiv) were used at room temperature.

b Isolated yield. Caution: most compounds above need handle with care for their low boiling point.

c Starting material of $21 \%$ was recovered. 
$3.259 \mathrm{mmol}$ ) in dry Et ${ }_{2} \mathrm{O}$. The resulting mixture was allowed to warm to room temperature and stirred for $1.5 \mathrm{~h}$. The reaction was quenched by the careful addition of satd $\mathrm{Na}_{2} \mathrm{~S}_{2} \mathrm{O}_{3}$ solution, and the resulting mixture was filtered through a Celite pad and the aqueous layer was extracted with DCM $(3 \times 20 \mathrm{~mL})$, and the combined organic phase was washed with brine, dried over $\mathrm{Na}_{2} \mathrm{SO}_{4}$, and concentrated under vacuum. The crude was purified by FC (silica gel, hexanes/EtOAc 5:1) to give compound 7 as a colorless oil (148 mg, 65\%). ${ }^{1} \mathrm{H} \mathrm{NMR}\left(400 \mathrm{MHz}, \mathrm{CDCl}_{3}\right) \delta: 6.26(\mathrm{~s}, 1 \mathrm{H}), 4.28(\mathrm{~s}, 2 \mathrm{H}), 3.10(\mathrm{~d}$, $J=1.6,2 \mathrm{H}), 1.90$ (s, 3H), 1.66 (br s, $1 \mathrm{H}) ;{ }^{13} \mathrm{C}$ NMR $\left(100 \mathrm{MHz}, \mathrm{CDCl}_{3}\right)$ $\delta$ 141.7, 81.9, 81.6, 77.2, 51.3, 28.6, 23.8; IR (film, $\mathrm{cm}^{-1}$ ): 2289, 2213, $1668,1627,1271,1012$; EI-HRMS calcd for $\mathrm{C}_{7} \mathrm{H}_{9} \mathrm{IO}, 235.9698$; found: $235.9701\left([\mathrm{M}]^{+}\right)$.

4.1.3. (E)-6-Bromo-1-iodo-2-methylhex-1-en-4-yne (5). To a solution of 7 (39 mg, $0.165 \mathrm{mmol}$ ) and $\mathrm{CBr}_{4}(72 \mathrm{mg}, 0.215 \mathrm{mmol})$ in dry DCM $(2 \mathrm{~mL})$ at $0{ }^{\circ} \mathrm{C}$ under $\mathrm{N}_{2}$ protection, was added $\mathrm{PPh}_{3}(65 \mathrm{mg}$, $0.248 \mathrm{mmol}$ ) portionwise. After $15 \mathrm{~min}$, the solution was warmed to room temperature and stirred for another $1 \mathrm{~h}$. The solvent was removed in vacuum and the crude was purified by FC (silica gel, hexanes) to give compound 5 as a light yellow oil (43 mg, 89\%). ${ }^{1} \mathrm{H}$ $\operatorname{NMR}\left(400 \mathrm{MHz}, \mathrm{CDCl}_{3}\right) \delta: 6.26(\mathrm{~s}, 1 \mathrm{H}), 3.93(\mathrm{t}, J=2.4,2 \mathrm{H}), 3.12(\mathrm{~d}$, $J=1.6,2 \mathrm{H}), 1.90(\mathrm{~s}, 3 \mathrm{H}) ;{ }^{13} \mathrm{C} \mathrm{NMR}\left(100 \mathrm{MHz}, \mathrm{CDCl}_{3}\right) \delta 141.4,83.4,77.5$, 77.2, 28.7, 23.8, 14.9; IR (film, $\mathrm{cm}^{-1}$ ): 2233, 1632, 1208, 1130, 611, 565; EI-HRMS calcd for $\mathrm{C}_{7} \mathrm{H}_{8} \mathrm{BrI}, 297.8854$; found: $297.8859\left([\mathrm{M}]^{+}\right)$.

4.1.4. (2R,5S)-2-tert-Butyl-5-((E)-6-iodo-5-methylhex-5-en-2-ynyl)5-methyl-1,3-dioxolan-4-one (8). To a solution of diisopropylamine (44 mg, $0.430 \mathrm{mmol})$ in THF $(1 \mathrm{~mL})$ at $-60{ }^{\circ} \mathrm{C}$ was added $n$-BuLi (0.173 mL, $0.415 \mathrm{mmol}, 2.4 \mathrm{M}$ in hexanes) dropwise. The solution was warmed to $-10^{\circ} \mathrm{C}$ over $1 \mathrm{~h}$ and then recooled to $-90^{\circ} \mathrm{C}$. Next, a solution of dioxolanone $4(66 \mathrm{mg}, 0.415 \mathrm{mmol})$ in THF $(1 \mathrm{~mL})$ was added slowly down the walls of the flask for precooling. The reaction mixture was stirred at $-90{ }^{\circ} \mathrm{C}$ for $10 \mathrm{~min}$ and then the bromide 5 (40 $\mathrm{mg}, 0.134 \mathrm{mmol}$ ) was added dropwise. The reaction mixture was warmed slowly to $-10^{\circ} \mathrm{C}$ over $2 \mathrm{~h}$ and then quenched with satd aqueous $\mathrm{NH}_{4} \mathrm{Cl}(1 \mathrm{~mL})$. The aqueous layer was extracted with EtOAc $(3 \times 20 \mathrm{~mL})$, and the combined organic phase was washed with brine, dried over $\mathrm{Na}_{2} \mathrm{SO}_{4}$, and concentrated under vacuum. The crude was purified by FC (silica gel, hexanes/EtOAc $20: 1)$ to give compound 8 as a pale yellow oil (42 mg, 85\%). $[\alpha]_{D}^{20}$ -10.2 (c 1.2, $\left.\mathrm{CHCl}_{3}\right) ;{ }^{1} \mathrm{H}$ NMR (400 MHz, $\left.\mathrm{CDCl}_{3}\right) \delta: 6.25(\mathrm{~s}, 1 \mathrm{H}), 5.37$ (s, $1 \mathrm{H}), 3.03(\mathrm{~s}, 2 \mathrm{H}), 2.70-2.57(\mathrm{~m}, 2 \mathrm{H}), 1.89(\mathrm{~s}, 3 \mathrm{H}), 1.48(\mathrm{~s}, 3 \mathrm{H})$, $0.96(\mathrm{~s}, 9 \mathrm{H}) ;{ }^{13} \mathrm{C}$ NMR $\left(100 \mathrm{MHz}, \mathrm{CDCl}_{3}\right) \delta 174.5,142.0,109.5,79.4$, 79.0, 77.2, 77.1, 34.6, 28.7, 27.8, 23.7, 23.3, 23.1; IR (film, $\mathrm{cm}^{-1}$ ): 2964, 2218, 1799, 1694, 1632, 1485, 1175, 1146, 1077, 983; EI-HRMS calcd for $\mathrm{C}_{15} \mathrm{H}_{21} \mathrm{IO}_{3}, 376.0535$; found: $376.0540\left([\mathrm{M}]^{+}\right)$.

\subsection{General experimental procedure for the partial hydrogenation}

To a solution of nickel acetate tetrahydrate $(72 \mathrm{mg}, 0.289 \mathrm{mmol})$ in EtOH ( $2 \mathrm{~mL}$ ) was added a solution of sodium borohydride (11 mg, $0.289 \mathrm{mmol})$ in EtOH $(0.5 \mathrm{~mL})$ quickly. The solution was stirred for $30 \mathrm{~min}$ and then added ethylenediamine $(7.5 \mu \mathrm{L}, 0.115 \mathrm{mmol})$ followed by addition of alkyne $(0.096 \mathrm{mmol})$ dissolved in EtOH $(0.2 \mathrm{~mL})$. The reaction mixture was stirred under $1 \mathrm{~atm}$ of hydrogen for a few minutes (2-5 min) and then removed the hydrogen tube. The reaction was monitored by TLC. Upon transformation of the starting material, water was added. The mixture was extracted with EtOAc, and the combined organic phase was washed with brine, dried over $\mathrm{Na}_{2} \mathrm{SO}_{4}$, and concentrated under vacuum. The crude was purified by FC (silica gel) to give the designed product.

4.2.1. (2Z,5E)-6-Iodo-5-methylhexa-2,5-dien-1-ol (9). Compound 9 was prepared in $77 \%$ yield after purification according to the general procedure as a colorless oil. ${ }^{1} \mathrm{H}$ NMR $\left(400 \mathrm{MHz}, \mathrm{CDCl}_{3}\right) \delta$ : $5.95(\mathrm{~s}, 1 \mathrm{H}), 5.75(\mathrm{dt}, J=6.4, J=11.2,1 \mathrm{H}), 5.54(\mathrm{dt}, J=7.6, J=10.8,1 \mathrm{H})$, $4.21(\mathrm{~d}, J=6.4,2 \mathrm{H}), 2.97$ (d, $J=7.6,2 \mathrm{H}), 1.84(\mathrm{~s}, 3 \mathrm{H}) ;{ }^{13} \mathrm{C}$ NMR $\left(100 \mathrm{MHz}, \mathrm{CDCl}_{3}\right) \delta 145.9,130.8,128.5,75.9,58.4,37.1,24.1$; IR (film, $\left.\mathrm{cm}^{-1}\right)$ : 3336, 2920, 2850, 1028, 766, 666; EI-HRMS calcd for $\mathrm{C}_{7} \mathrm{H}_{11} \mathrm{IO}, 237.9855$; found: $237.9860\left([\mathrm{M}]^{+}\right)$.

4.2.2. tert-Butyl-(2Z,5E)-6-iodo-5-methylhexa-2,5-dienyloxy)dimethylsilane (11). Compound 11 was prepared in 91\% yield after purification according to the general procedure as a light yellow oil. ${ }^{1} \mathrm{H}$ $\operatorname{NMR}\left(400 \mathrm{MHz}, \mathrm{CDCl}_{3}\right) \delta: 5.93(\mathrm{~s}, 1 \mathrm{H}), 5.66(\mathrm{dt}, J=6.0, J=11.2,1 \mathrm{H})$, $5.42(\mathrm{dt}, J=7.6, J=11.2,1 \mathrm{H}), 4.22(\mathrm{~d}, J=6.0,2 \mathrm{H}), 2.93(\mathrm{~d}, J=7.2,2 \mathrm{H}), 1.83$ $(\mathrm{s}, 3 \mathrm{H}), 0.90(\mathrm{~s}, 9 \mathrm{H}), 0.07(\mathrm{~s}, 6 \mathrm{H}) ;{ }^{13} \mathrm{C}$ NMR $\left(100 \mathrm{MHz}, \mathrm{CDCl}_{3}\right) \delta$ 146.0, 132.0, 126.4, 75.7, 59.2, 37.3, 25.9, 24.1, 18.3, -5.2; IR (film, $\mathrm{cm}^{-1}$ ): 2954, 2929, 2856, 1661, 1254, 1101, 776, 667; HRMS (EI) peaks and HRMS $\left(\mathrm{ESI}^{+}\right.$) peaks due to $[\mathrm{M}+\mathrm{H}]^{+}$or $[\mathrm{M}+\mathrm{Na}]^{+}$were not detected.

4.2.3. (2Z,5E)-6-Iodo-5-methylhexa-2,5-dienyl benzoate (13). Compound 13 was prepared in 73\% yield (recovered 20\% SM) after purification according to the general procedure as a pale yellow oil. ${ }^{1} \mathrm{H}$ NMR $\left(400 \mathrm{MHz}, \mathrm{CDCl}_{3}\right) \delta$ : 8.05-8.03 (m, $\left.2 \mathrm{H}\right)$, $7.58-7.52(\mathrm{~m}, 1 \mathrm{H}), 7.46-7.42(\mathrm{~m}, 2 \mathrm{H}), 6.00(\mathrm{~s}, 1 \mathrm{H}), 5.83(\mathrm{dt}, J=6.8$, $J=11.2,1 \mathrm{H}), 5.42(\mathrm{dt}, J=7.6, J=10.8,1 \mathrm{H}), 4.87(\mathrm{~d}, J=6.8,2 \mathrm{H}), 3.07$ $(\mathrm{d}, J=7.6,2 \mathrm{H}), 1.87(\mathrm{~s}, 3 \mathrm{H}) ;{ }^{13} \mathrm{C}$ NMR $\left(100 \mathrm{MHz}, \mathrm{CDCl}_{3}\right) \delta 166.4$, 145.5, 133.0, 131.1, 130.1, 129.6, 128.4, 125.9, 76.2, 60.3, 37.3, 24.1; IR (film, $\mathrm{cm}^{-1}$ ): 2923, 1717, 1601, 1584, 1451, 768, 711; HRMS (EI) peaks and HRMS $\left(\mathrm{ESI}^{+}\right)$peaks due to $[\mathrm{M}+\mathrm{H}]^{+}$or $[\mathrm{M}+\mathrm{Na}]^{+}$were not detected.

4.2.4. (E)-1-Iodo-2-methylpenta-1,4-dien-3-ol (15). Compound $\mathbf{1 5}$ was prepared in $73 \%$ yield after purification according to the general procedure as a pale yellow oil. ${ }^{1} \mathrm{H}$ NMR $\left(400 \mathrm{MHz}, \mathrm{CDCl}_{3}\right) \delta$ : $6.40(\mathrm{~s}, 1 \mathrm{H}), 5.86-5.78(\mathrm{~m}, 1 \mathrm{H}), 5.35-5.21(\mathrm{~m}, 2 \mathrm{H}), 4.67(\mathrm{~d}, J=5.6$, $1 \mathrm{H}), 1.81(\mathrm{~s}, 3 \mathrm{H}) ;{ }^{13} \mathrm{C}$ NMR (100 MHz, $\left.\mathrm{CDCl}_{3}\right) \delta$ 148.1, 137.8, 116.5, 78.9, 78.2, 20.3; IR (film, $\mathrm{cm}^{-1}$ ): 3398, 2955, 2918, 1462, 1377; EIHRMS calcd for C6H9IO, 223.9698; found: 223.9701 ([M] $\left.{ }^{+}\right)$.

4.2.5. 2-Iodopenta-1,4-dien-3-ol (17). Compound 17 was prepared in $81 \%$ yield after purification according to the general procedure as a colorless oil. ${ }^{1} \mathrm{H}$ NMR $\left(400 \mathrm{MHz}, \mathrm{CDCl}_{3}\right) \delta: 6.45-6.44(\mathrm{~m}, 1 \mathrm{H}), 5.92$ (d, $J=1.6,1 \mathrm{H}$ ), 5.84 (ddd, $J=5.2, J=10.4, J=15.6,1 \mathrm{H}$ ), 5.42 (dt, $J=1.2$, $17.2,1 \mathrm{H}), 5.33(\mathrm{dt}, J=1.2,10.4,1 \mathrm{H}), 4.37(\mathrm{~s}, 1 \mathrm{H}), 1.56$ (br s, $1 \mathrm{H}) ;{ }^{13} \mathrm{C}$ NMR $\left(100 \mathrm{MHz}, \mathrm{CDCl}_{3}\right) \delta 137.5,125.9,117.5,115.7,78.5$; IR (film, $\mathrm{cm}^{-1}$ ): 3405, 3081, 2924, 2854, 1640, 1631, 1082, 1038, 990, 910; HRMS (EI) peaks and HRMS $\left(\mathrm{ESI}^{+}\right)$peaks due to $[\mathrm{M}+\mathrm{H}]^{+}$or $[\mathrm{M}+\mathrm{Na}]^{+}$were not detected.

4.2.6. (E)-8-Iodo-7-methylocta-1,7-dien-4-yn-3-ol (19). Compound 19 was prepared in $75 \%$ yield (recovered $25 \% \mathrm{SM}$ ) after purification according to the general procedure as a colorless oil. ${ }^{1} \mathrm{H}$ NMR $\left(400 \mathrm{MHz}, \mathrm{CDCl}_{3}\right) \delta: 6.25$ (s, $\left.1 \mathrm{H}\right), 5.97$ (ddd, $J=5.2,10.0,15.2,1 \mathrm{H}$ ), 5.44 (d, $J=17.2,1 \mathrm{H}), 5.22$ (d, $J=10.4,1 \mathrm{H}), 4.89$ (dd, $J=1.2,3.6,1 \mathrm{H}$ ), $3.12(\mathrm{~s}, 2 \mathrm{H}), 1.90(\mathrm{~s}, 3 \mathrm{H}) ;{ }^{13} \mathrm{C} \mathrm{NMR}\left(100 \mathrm{MHz}, \mathrm{CDCl}_{3}\right) \delta$ 141.6, 137.2, 116.4, 82.5, 82.2, 77.2, 63.4, 28.6, 23.8; IR (film, $\mathrm{cm}^{-1}$ ): 3359, 3065, 2914, 2878, 2247, 2210, 1643, 1416, 1378, 928; EI-HRMS calcd for $\mathrm{C}_{9} \mathrm{H}_{11} \mathrm{IO}, 261.9855$; found: $261.9858\left([\mathrm{M}]^{+}\right)$.

4.2.7. (4Z,7E)-8-Iodo-7-methylocta-1,4,7-trien-3-ol (20). Compound $\mathbf{2 0}$ was prepared in $83 \%$ yield after purification according to the general procedure as a colorless oil. ${ }^{1} \mathrm{H}$ NMR $\left(400 \mathrm{MHz}, \mathrm{CDCl}_{3}\right) \delta$ : $5.96(\mathrm{~s}, 1 \mathrm{H}), 5.89$ (ddd, $J=6.0,10.4,16.8,1 \mathrm{H}), 5.58-5.49(\mathrm{~m}, 2 \mathrm{H}), 5.26$ $(\mathrm{d}, J=17.6,1 \mathrm{H}), 5.14(\mathrm{~d}, J=10.4,1 \mathrm{H}), 4.94-4.93(\mathrm{~m}, 1 \mathrm{H}), 3.00(\mathrm{~d}, J=6.0$, $2 \mathrm{H}), 1.85$ (s, 3H); ${ }^{13} \mathrm{C}$ NMR (100 MHz, $\left.\mathrm{CDCl}_{3}\right) \delta 145.7,139.2,132.7$, 128.1, 115.1, 76.1, 68.9, 37.3, 24.1; IR (film, $\mathrm{cm}^{-1}$ ): 3364, 3066, 2964, $2878,1642,1619,987,926,765,669$; EI-HRMS calcd for $\mathrm{C}_{9} \mathrm{H}_{13} \mathrm{IO}$, 264.0011; found: $263.9898\left([\mathrm{M}]^{+}\right)$. 
4.2.8. (2R,5S)-2-tert-Butyl-5-((2Z,5E)-6-iodo-5-methylhexa-2,5dienyl)-5-methyl-1,3-dioxolan-4-one (3). Compound 3 was prepared in $79 \%$ yield after purification according to the general procedure as a pale yellow oil. $[\alpha]_{\mathrm{D}}^{20}-13.5\left(\mathrm{c} 0.4, \mathrm{CHCl}_{3}\right) ;{ }^{1} \mathrm{H}$ NMR $\left(400 \mathrm{MHz}, \mathrm{CDCl}_{3}\right) \delta: 5.93(\mathrm{~s}, 1 \mathrm{H}), 5.65-5.56(\mathrm{~m}, 2 \mathrm{H}), 5.18(\mathrm{~s}, 1 \mathrm{H})$, 2.95 (d, $J=5.2,2 \mathrm{H}), 2.55-2.45(\mathrm{~m}, 2 \mathrm{H}), 1.84(\mathrm{~s}, 3 \mathrm{H}), 1.44(\mathrm{~s}, 3 \mathrm{H})$, $0.94(\mathrm{~s}, 9 \mathrm{H}) ;{ }^{13} \mathrm{C}$ NMR $\left(100 \mathrm{MHz}, \mathrm{CDCl}_{3}\right) \delta 175.4,145.8,130.6$, 124.2, 108.8, 79.9, 75.8, 37.0, 34.6, 34.2, 24.2, 23.3, 23.0; IR (film, $\left.\mathrm{cm}^{-1}\right)$ : 2963, 1798, 1682, 1632, 1485, 1172, 1140, 1078, 983, 793, 768; EI-HRMS calcd for $\mathrm{C}_{15} \mathrm{H}_{23} \mathrm{IO}_{3}, 378.0692$; found: 378.0697 $\left([\mathrm{M}]^{+}\right)$.

\section{Acknowledgements}

This work was supported by NNSF of China (Projects 2012CB822101, 21072217, 21202193, and 2012ZX09502001).

\section{Supplementary data}

Supplementary data associated with this article can be found in the online version, at http://dx.doi.org/10.1016/j.tet.2012.12.008.

\section{References and notes}

1. For selected reviews, see: Nicolaou, K. C.; Bulger, P. G.; Sarlah, D. Angew. Chem., Int. Ed. 2005, 44, 4442-4489; (b) Negishi, E.; Huang, Z.; Wang, G.; Mohan, S.; Wang, C.; Hattori, H. Acc. Chem. Res. 2008, 41, 1474-1485; For recent examples see: (c) DeBerardinis, A. M.; Turlington, M.; Pu, L. Angew. Chem., Int. Ed. 2011, 50 , 2368-2370; (d) Lehr, K.; Mariz, R.; Leseurre, L.; Gabor, B.; Fürstner, A. Angew. Chem., Int. Ed. 2011, 50, 11373-11377; (e) Yadav, J. S.; Reddy, K. B.; Sabitha, G. Tetrahedron 2008, 64, 1971-1982.

2. For recent reviews, see: (a) Chinchilla, R.; Najera, C. Chem. Soc. Rev. 2011, 40, 5084-5121; (b) McGlacken, G. P.; Fairlamb, I. J. S. Eur. J. Org. Chem. 2009, 4011-4029.

3. For representative methods, see: (a) Marshall, J. A.; Bourbeau, M. P. Org. Lett. 2002, 4, 3931-3934; (b) Wong, T.; Tjepkema, M. W.; Audrain, H.; Wilson, P. D.; Fallis, A. G. Tetrahedron Lett. 1996, 37, 755-758; (c) Zhao, K.; Stork, G.
Tetrahedron Lett. 1989, 30, 2173-2174; (d) Takai, K.; Nitta, K.; Utimoto, K. J. Am. Chem. Soc. 1986, 108, 7408-7410; (e) Negishi, E.; Van Horn, D. E.; Yoshida, T. J. Am. Chem. Soc. 1985, 107, 6639-6647; (f) Hart, D. W.; Blackburn, T. F.; Schwartz, J. J. Am. Chem. Soc. 1975, 97, 679-680; (g) Darwish, A.; Chong, J. M. Tetrahedron 2012, 68, 654-658.

4. (a) Denton, R. W.; Parker, K. A. Org. Lett. 2009, 11, 2722-2723; (b) Arefolov, A ; Panek, J. S. Org. Lett. 2002, 4, 2397-2400; (c) Arefolov, A.; Panek, J. S. J. Am. Chem. Soc. 2005, 127, 5596-5603; (d) de Lemos, E.; Porée, F. H.; Bourin, A.; Barbion, J.; Agouridas, E.; Lannou, M. I.; Commerçon, A.; Betzer, J. F.; Pancrazi, A.; Ardisson, J. Chem.-Eur. J. 2008, 14, 11092-11112.

5. Sandler, J. S.; Colin, P. L.; Kelly, M.; Fenical, W. J. Org. Chem. 2006, 71, 7245-7251.

6. (a) Larivée, A.; Unger, J. B.; Thomas, M.; Wirtz, C.; Dubost, C.; Handa, S. Fürstner, A. Angew. Chem., Int. Ed. 2011, 50, 304-309; (b) Chellat, M. F.; Proust, N.; Lauer, M. G.; Stambuli, J. P. Org. Lett. 2011, 13, 3246-3249.

7. (a) Seebach, D.; Naef, R.; Calderari, G. Tetrahedron 1984, 40,1313-1324; (b) Tietze, L F.; Singidi, R. R.; Gericke, K. M. Chem.-Eur. J. 2007, 13, 9939-9947; For the conversion of dioxolanone into corresponding $\alpha$-hydroxy acid or methyl ester under mild conditions, see: (c) Blay, G.; Fernandez, I.; Monje, B.; Montesinos-Magraner M.; Pedro, J. R. Tetrahedron 2011, 67, 881-890; (d) Battaglia, A.; Baldelli, E.; Barbaro G.; Giorgianni, P.; Guerrini, A.; Monari, M.; Selva, S. Tetrahedron: Asymmetry 2002, $13,1825-1832$

8. Xu, B. M.; Shan, S. X.; Zhu, X. Y. Chin. Chem. Lett. 1993, 4, 13-16.

9. (a) White, J. D.; Sundermann, K. F.; Carter, R. G. Org. Lett. 1999, 1, 1431-1434; (b) Li, Y.; Zhou, F.; Forsyth, C. J. Angew. Chem., Int. Ed. 2007, 46, 279-282; (c) Caruso, T.; Spinella, A. Tetrahedron 2003, 59, 7787-7790.

10. (a) Fürstner, A.; Bouchez, L. C.; Funel, J. A.; Liepins, V.; Porée, F. H.; Gilmour, R. Beaufils, F.; Laurich, D.; Tamiya, M. Angew. Chem., Int. Ed. 2007, 46, 9265-9270; (b) Fürstner, A.; Bouchez, L. C.; Morency, L.; Funel, J. A.; Liepins, V.; Porée, F. H.; Gilmour, R.; Laurich, D.; Beaufils, F.; Tamiya, M. Chem.-Eur. J. 2009, 15 3983-4010; (c) Paterson, I.; Steadman neé Doughty, V. A.; McLeod, M. D.; Trieselmann, T. Tetrahedron 2011, 67, 10119-10128.

11. (a) Lindlar, H. Helv. Chim. Acta 1952, 35, 446-450; (b) Lindlar, H.; Dubuis, R. Org. Synth. 1966, 46, 89-91.

12. (a) Treilhou, M.; Fauve, A.; Pougny, J. R.; Prome, J. C.; Veschambre, H. J. Org. Chem. 1992, 57, 3203-3208; (b) Foucher, V.; Guizzardi, B.; Groen, M. B.; Light, M.; Linclau, B. Org. Lett. 2010, 12, 680-683.

13. (a) Brown, C. A.; Ahuja, V. K. J. Chem. Soc., Chem. Commun. 1973, 553-554; (b) Brown, C. A.; Ahuja, V. K.J. Org. Chem. 1973, 38, 2226-2230; For recent application of P2-Ni catalyst in the semihydrogenation of alkyne, see: (c) Dussault, P. H.; Eary, C. T.; Woller, K. R. J. Org. Chem. 1999, 64, 1789-1797; (d) Lehr, K.; Fürstner, A Tetrahedron 2012, 68, 7695-7700; (e) Kyle, A. F.; Jakubec, P.; Cockfield, D. M.; Cleator, E.; Skidmore, J.; Dixon, D. J. Chem. Commun. 2011, 10037-10039.

14. In Ref. 4a, the semihydrogenation of the propargyl alcohols with vinyl iodide over $\mathrm{Pd} / \mathrm{CaCO}_{3}$ in hexane was achieved after 4 days in $0.03 \mathrm{mmol}$ scale. 